\title{
Observed Ground Pressure Acting on the Lining of a Large-Diameter Shield Tunnel in Sandy Stratum under High Water Pressure
}

\author{
Xue Li $\mathbb{D}^{1,2}$ Shunhua Zhou ${ }^{1}{ }^{2,3}$ and Honggui Di $\mathbb{D}^{2,3}$ \\ ${ }^{1}$ School of Geoscience and Technology, Southwest Petroleum University, Chengdu, Sichuan 610500, China \\ ${ }^{2}$ Shanghai Key Laboratory of Rail Infrastructure Durability and System Safety, Tongji University, Shanghai 201804, China \\ ${ }^{3}$ Key Laboratory of Road and Traffic Engineering, Ministry of Education, Tongji University, Shanghai 201804, China
}

Correspondence should be addressed to Honggui Di; 2012dihonggui@tongji.edu.cn

Received 25 July 2019; Accepted 21 January 2020; Published 9 March 2020

Academic Editor: Timo Saksala

Copyright $(2020$ Xue Li et al. This is an open access article distributed under the Creative Commons Attribution License, which permits unrestricted use, distribution, and reproduction in any medium, provided the original work is properly cited.

Accurately evaluating the ground pressure on the tunnel lining greatly helps the structure design of a tunnel. In this study, the earth pressure and water pressure on the tunnel lining of four cross sections of a metro tunnel were measured and analyzed and then compared with the theoretical values. Results show that the values and distribution of observed ground pressure acting on the lining are different for different overburden depths. The water pressure measured on-site is approximately equal to the theoretical hydrostatic pressure. The water pressure acting on the shield tunnel lining does not fluctuate with the shield tunnel excavation. The maximum ground pressure was measured in the process of backfill grouting, and the maximum values are approximately larger than $30 \%$ of the stable value of the measured pressure. For a shield tunnel under a river with deep water, the water pressure on the lining is dominant and the observed total ground pressure is nearly equal to the water pressure. The findings presented in this paper can provide a reference for the structure design of similar tunnel projects.

\section{Introduction}

In recent decades, there has been an increase in applications of shield machines for the excavation of tunnels in large cities, especially under severe conditions, such as highdensity utilization of urban space, because shield tunnelling can effectively control and minimize ground settlement. Shield tunnelling construction methods are significantly developed and include synchronous backfill grouting, tail sealing, and special-shaped shield tunnelling. However, current design techniques cannot appropriately implement innovative construction techniques. The earth pressure acting on the lining is the primary load for the structural design of a shield tunnel. To date, overburden earth pressure or loosening earth pressure calculated by Terzaghi's formula has generally been adopted as the vertical earth pressure on the upper part of segmental lining [1]. The current study shows the most critical load making tail brush passing, and the conservative design loads mentioned indicated that earth pressure is rather smaller for a sound ground, while the design vertical earth pressure adopted a minimum limit of earth pressure. Many cases show that the tunnel structural design using the common method seems to be conservative $[2,3]$, meaning that accurately evaluating the earth pressure on the tunnel lining will help the structural design. It is critical to estimate and determine the load around the tunnel.

Multiple factors influencing the earth pressure around the tunnel lining, including the engineering geology, the depth of the overburden, the ground water level, the excavation method, interactions between the lining and soil and the construction behaviour, operational parameters, and grouting parameters, have been indicated by many scholars [4-6].

Model tests and field measurements have been carried out to investigate the mechanical behaviour around tunnel 
lining. Some previous field measurements have shown that the actual load acting on the shield tunnel lining could be much smaller than that adopted for the designs, especially for good ground conditions [7-10]. The change from fluid and solid states of the backfill grout at different stages influences the load on the lining. The observed pressure demonstrated that the backfill grouting volume and pressure have significant influences on the earth pressure around the tunnel lining $[3,8]$. Some studies investigated the earth pressure on the lining of shield tunnels with shallow overburdens in silty-sandy ground and stated that the loads imposed during construction cannot be neglected due to the soil displacements and lining force induced by the construction [11]. The earth pressure at the tunnel sides and the lining pressure change depending on the lateral deformation of the ground [2]. The method of the conventional designs of shield tunnel linings seems to be conservative $[3,8]$. Therefore, it is necessary to improve this method and to develop more rational design methods in the future. Hashimoto et al. [12] stated that the change in pressure with time during the tail passing can be divided into 4 phases. There are different ground pressure distributions on the shield lining in various strata. Based on the observed data, Hashimoto et al. [12] indicated that lining pressure was almost the same as the initial earth pressure in soft strata, and the pressure on the lining was the loose earth pressure plus the water pressure in sand strata. Because the actual earth pressure cannot be predicted correctly by conventional methods, especially for a deep shield tunnel, some researchers have proposed a new model to calculate the vertical earth pressure based on the finite method theory [13].

There are very few cases that measure the earth pressures and water pressures acting on the lining on-site $[1,2]$, especially for cases with deep tunnel depth and with high water pressure. In this research, the observed ground pressure on a large-diameter shield tunnel lining at different depths is presented in-field, and the relationship between the earth pressure and time is demonstrated. The measured earth pressures and water pressures are compared to the theoretical value adopted in the tunnel lining design. The factors influencing the earth pressure are also discussed.

\section{Description of the Tunnel Project}

2.1. Yangtze River Tunnel of Nanjing Metro Line No. 3. The Nanjing Yangtze River Tunnel for Metro Line No. 3 is located in the lower reaches of the Yangtze River (see Figure 1). Metro Line No. 3 is the line that connects both sides of the Yangtze River in western Nanjing. The tunnel below the river was excavated by a slurry shield machine with an outer diameter of $11.64 \mathrm{~m}$. The internal and external diameters of the tunnel are $10.2 \mathrm{~m}$ and $11.2 \mathrm{~m}$, respectively. The tunnel lining is reinforced concrete, and each ring of the lining is $0.5 \mathrm{~m}$ thick and $2 \mathrm{~m}$ wide. The tunnel lining ring consists of 8 segments: five standard segments, two adjacent segments, and one key segment. Common tapered segments of precast reinforced concrete are assembled with staggered joints. Skew bolts are used to connect segments in the longitudinal and circumferential directions. The maximum water pressure in the ground at the depth of the tunnel is approximately $0.65 \mathrm{MPa}$. The geotechnical strata from the surface along the route of the bored tunnel comprise multiple layers of soil with varying thicknesses, including man-made ground, muddy silty clay, silty clay, silt, fine sand, medium coarse sand, pebbles, rounded gravels, and mudstone. The Yangtze River Tunnel of Metro Line No. 3 is situated mainly within the silty sand and fine sand strata [14]. The total length between the two stations and the length of the riving-crossing portion for Metro Line No. 3 are $3,353 \mathrm{~m}$ and 2,158 $\mathrm{m}$, respectively. The longitudinal profile of the tunnel is shown in Figure 2, and the four tunnel sections measured on-site have overburdens of $34.10 \mathrm{~m}, 14.97 \mathrm{~m}$, $12.90 \mathrm{~m}$, and $12.48 \mathrm{~m}$, respectively. The corresponding soil properties are summarized in Table 1.

2.2. Monitoring Procedure. To monitor the load on the lining and the load behaviour during construction of a shield tunnel, field measurements on the earth pressure and water pressure were performed at four cross sections of the shield tunnel of the Nanjing Metro Line No. 3. The geological profiles of these four monitoring sections are shown in Figure 3, and the basic parameters of these four monitored sections are shown in Table 2. Section-a (Ring 479) of the shield tunnel is located below the Yangtze River levee, the overburden of the section is $34.1 \mathrm{~m}$, and the water level is $4.96 \mathrm{~m}$ below the ground level. Section-b (ring 1094), Section-c (ring 1210), and Section-d (ring 1384) are all located below the Yangtze River. The overburdens of Sections b, c, and $\mathrm{d}$ are $14.97 \mathrm{~m}, 12.9 \mathrm{~m}$, and $12.48 \mathrm{~m}$, respectively, and the river levels of these three sections are $42.24 \mathrm{~m}, 37.36 \mathrm{~m}$, and $29.67 \mathrm{~m}$, respectively. The earth pressure on the lining was measured by placing earth pressure metres behind the segments, and the water pressure was measured using ground water flowing into the bored holes, as shown in Figure 4 . The measured earth pressure is considered to be the total ground earth pressure, including pore-water pressure. The layout of the earth pressure cell in-site is shown in Figure 5. The experiment focuses on the measurement of the earth pressure and water pressure and describes the earth pressure and water pressure associated with various factors.

\section{Field Measurement Results}

3.1. The Earth Pressure and Water Pressure over Time. The cross sections of the shield tunnel lining used for the measurements are all located in the sandy stratum. Figure 6 shows the changes of the earth pressure and water pressure acting on the lining with time. The measurement time lasted for approximately between 100 days and 300 days after the shield tail passed.

As shown in Figure 6(a), the total earth pressure acting on the lining reaches a maximum approximately four months after tail passing. The reason may be construction disturbances, that is, simultaneous grouting hardening, transportation lining segments, and/or the behaviour of the second grouting. Among the three total pressures acting on 


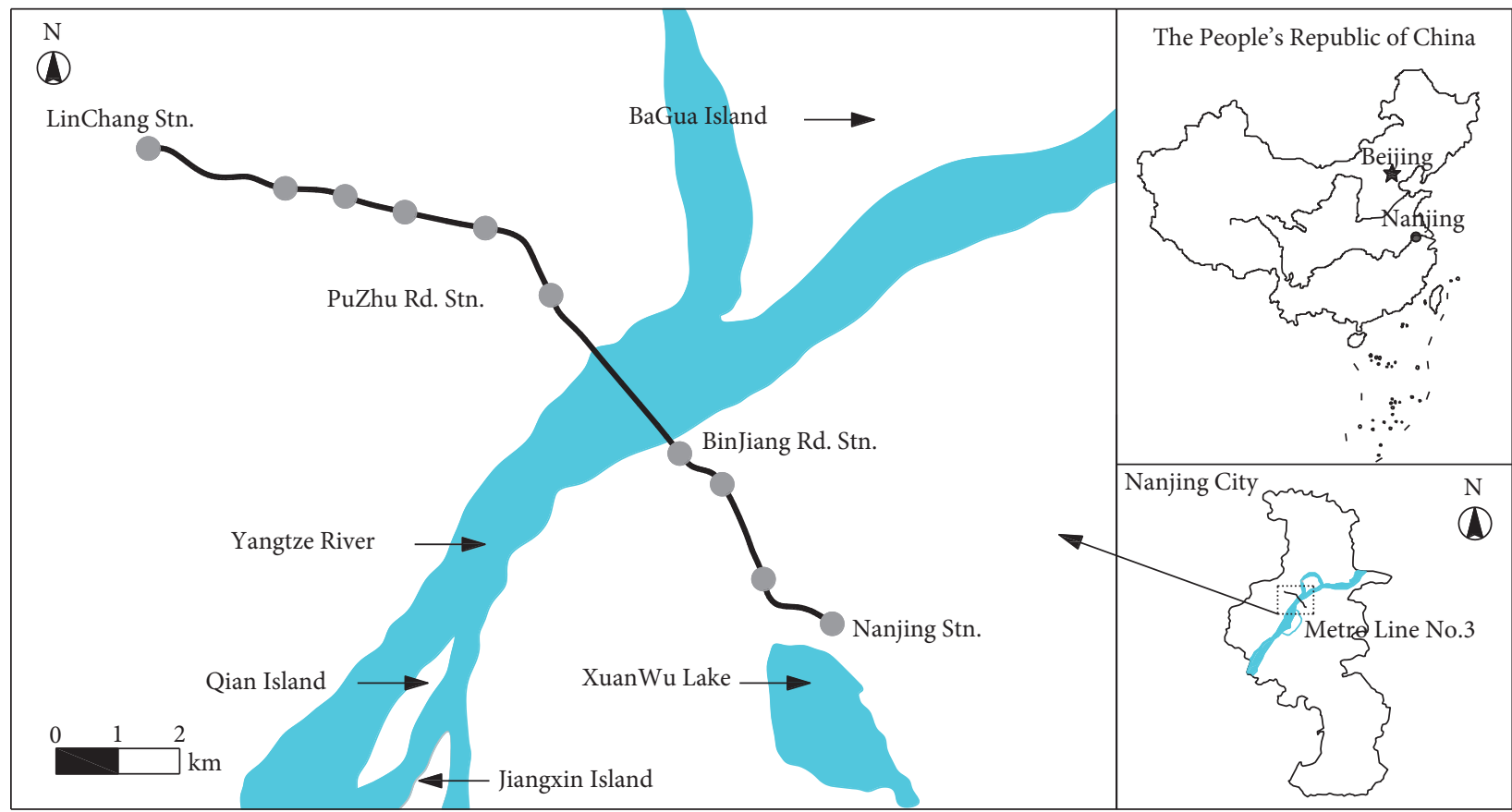

Station

Underground line

FIGURE 1: Location of the project.

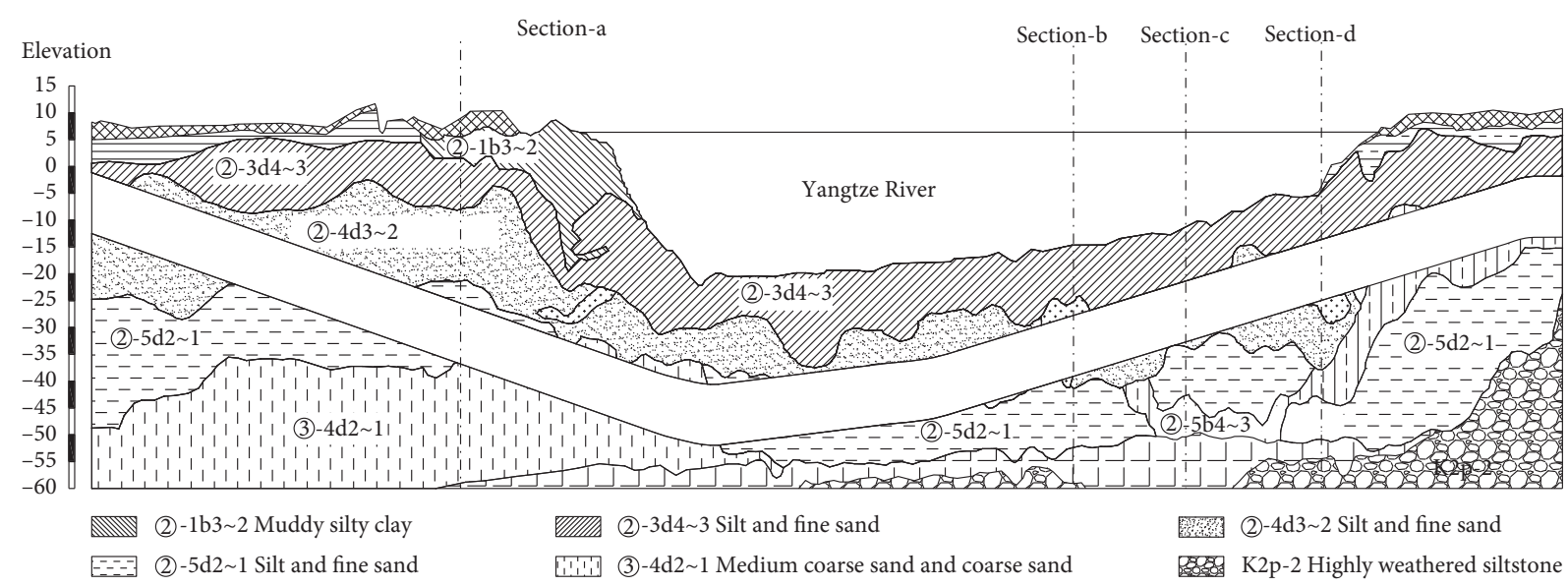

Figure 2: Longitudinal soil profile along the tunnel.

TABle 1: Basic physical and mechanical properties of the soils.

\begin{tabular}{lccccccccc}
\hline Soil stratum & $w(\%)$ & $\gamma\left(\mathrm{kN} / \mathrm{m}^{3}\right)$ & $e$ & $E_{s}(\mathrm{MPa})$ & $C(\mathrm{kPa})$ & $\varphi\left({ }^{\circ}\right)$ & $f(\mathrm{kPa})$ & $C_{u}$ & $C_{c}$ \\
\hline Muddy silty clay & 39.7 & 18.9 & 1.135 & 3.45 & 11 & 5.4 & 65 & 9.710 & 2.480 \\
Silt and fine sand & 24.6 & 19.4 & 0.724 & 15.47 & 8 & 31.8 & 180 & 6.72 & 2.51 \\
Medium coarse sand and coarse sand & 20.5 & 20.1 & 0.612 & 15.2 & 10 & 31.1 & 300 & 13.66 & 2.93 \\
Pebbles & - & 22.55 & - & - & - & - & - & 38.55 & 2.30 \\
\hline
\end{tabular}

The table is reproduced from Zhou et al. [6]. $w=$ water content, $\gamma=$ natural unit weight of the soil, $e=$ void ratio, $E_{s}=$ compression modulus of the soil, $C=$ cohesion, $\varphi=$ angle of internal friction, $f=$ bearing capacity of the ground, $C_{u}=$ the uniformity coefficient, and $C_{c}=$ the curvature coefficient. Values for $C$ and $\varphi$ were obtained from consolidated-undrained (CU) triaxial tests.

the lining, the pressure on the bottom is the largest, and the maximum value of the total earth pressure on the lining bottom is equal to $819 \mathrm{kPa}$. In addition, the measured total earth pressure had experienced three stages. The measured earth pressure fluctuated a week after tail passing. The measured total earth pressure acting on the crown level and 


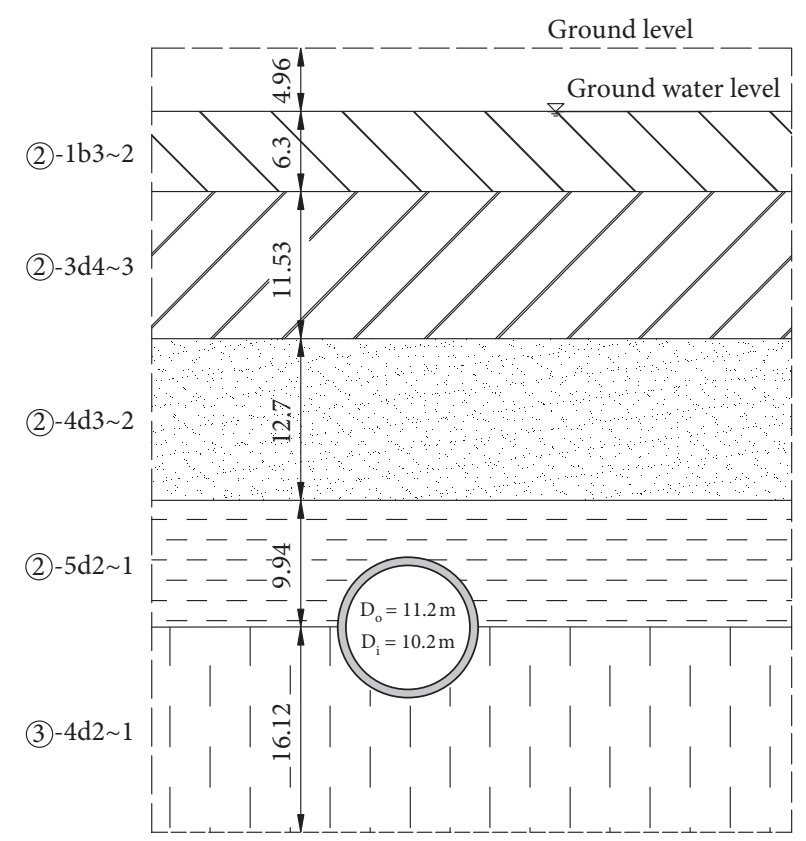

(a)

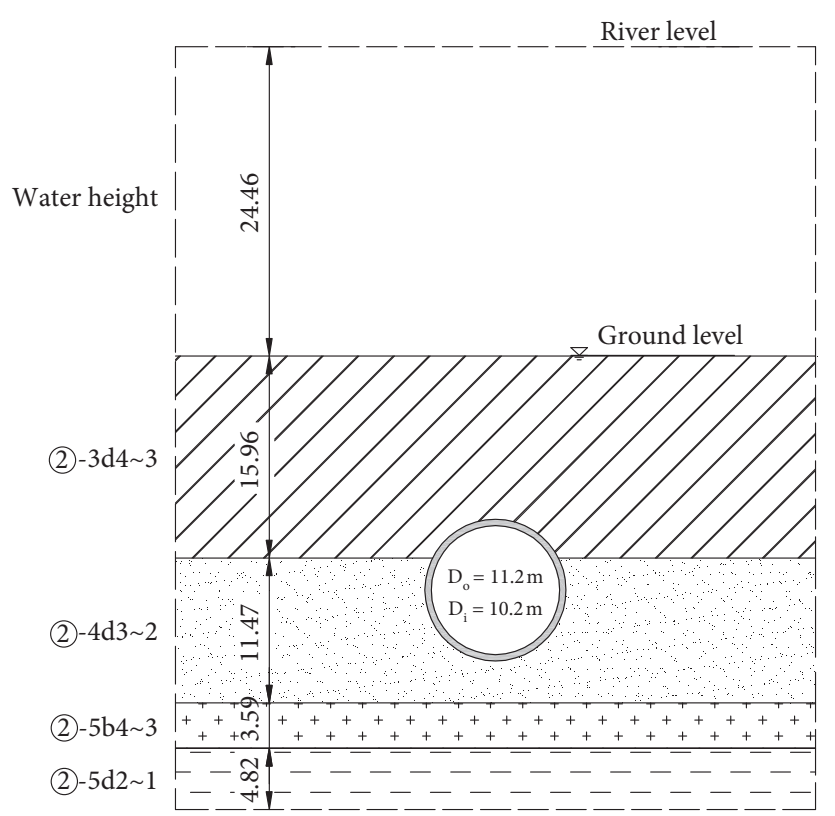

(c)

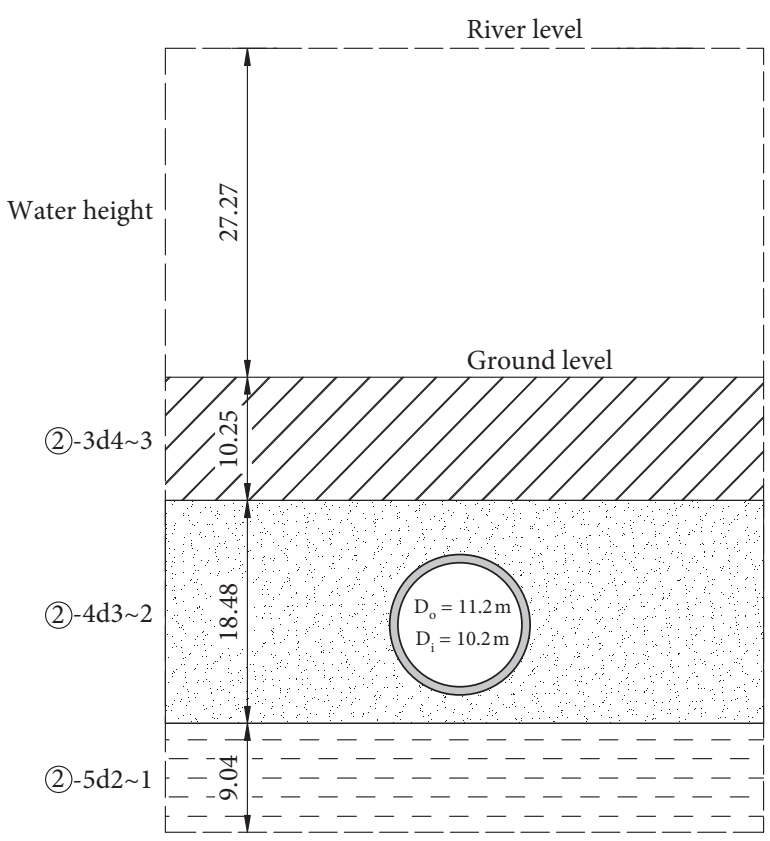

(b)

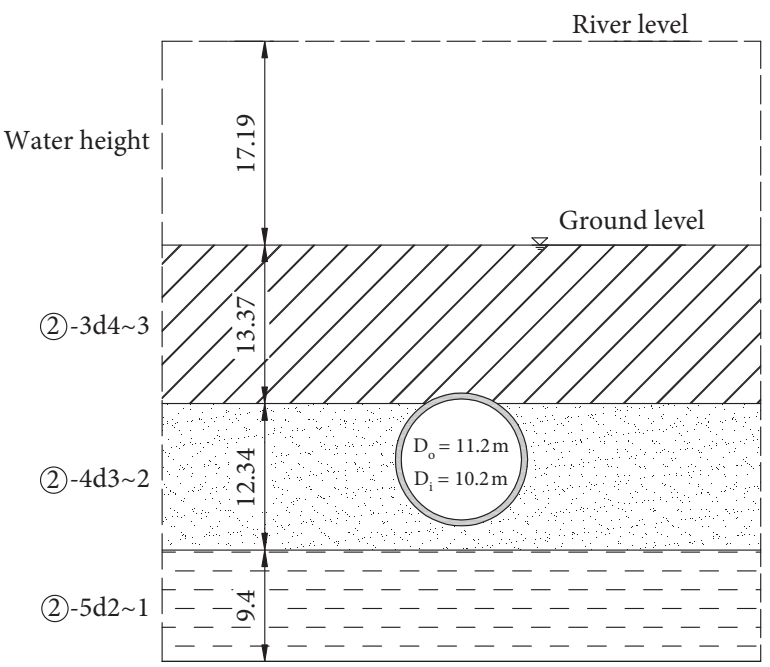

(d)

FIGURE 3: Geological profile of the monitoring sections: (a) Section-a (ring 479), (b) Section-b (ring 1094), (c) Section-c (ring 1210), and (d) Section-d (ring 1384).

TABLE 2: Basic parameters of the monitored sections of the project.

\begin{tabular}{|c|c|c|c|c|}
\hline Section (ring number) & $\begin{array}{l}\text { Section-a } \\
\text { (ring 479) }\end{array}$ & $\begin{array}{c}\text { Section-b } \\
\text { (ring 1094) }\end{array}$ & $\begin{array}{c}\text { Section-c } \\
\text { (ring 1210) } \\
\end{array}$ & $\begin{array}{r}\text { Section-d } \\
\text { (ring 1384) }\end{array}$ \\
\hline Height of overburden $(H)(\mathrm{m})$ & 34.1 & 14.97 & 12.9 & 12.48 \\
\hline Water level on the crown level $\left(H_{\mathrm{w}}\right)(\mathrm{m})$ & 30.7 & 42.24 & 37.36 & 29.67 \\
\hline Overburden soil depth $(H) /$ tunnel outer diameter $\left(D_{\mathrm{o}}\right)$ & 3.04 & 1.34 & 1.15 & 1.11 \\
\hline
\end{tabular}




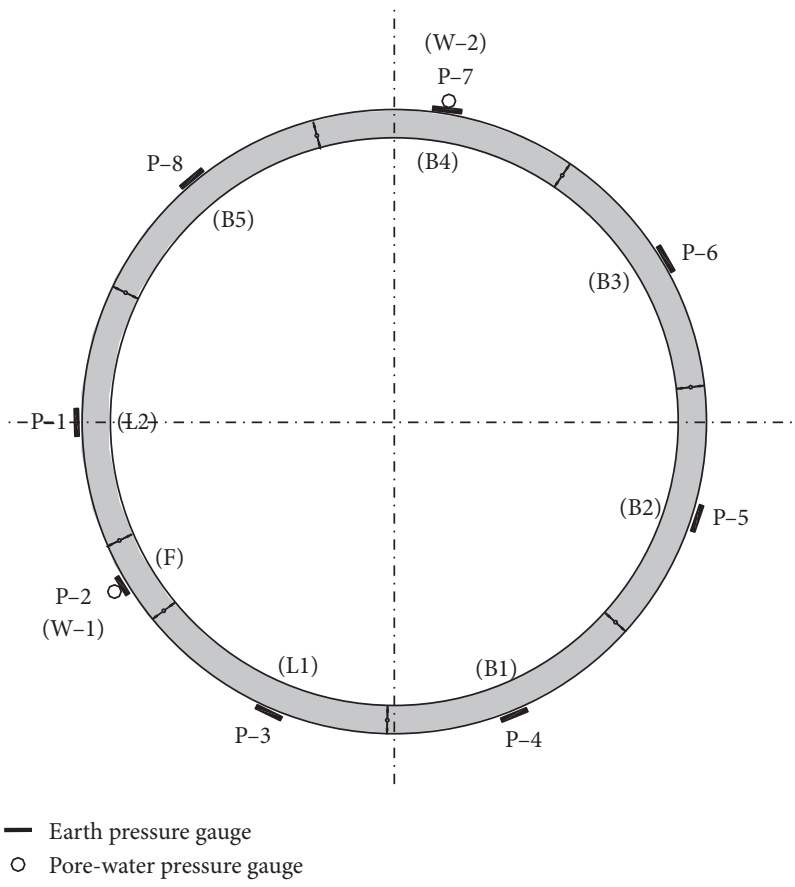

FIgURE 4: Layout of the earth pressure cells and water gauges in the tunnel lining.

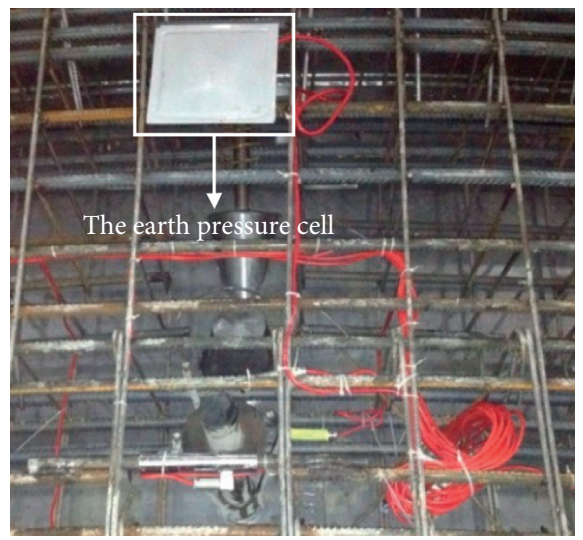

(a)

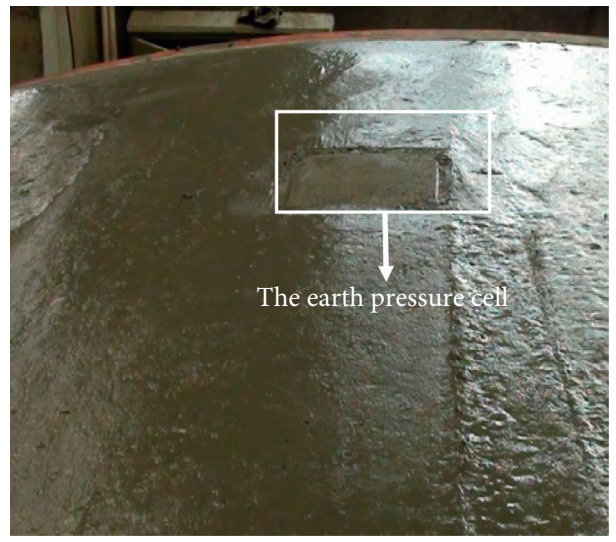

(b)

Figure 5: Photos of the earth pressure cell: (a) before segment lining concrete casting and (b) after segment lining concrete casting.

on the bottom level went a growing rate during the time between 2 and 4 months after tail passing. The measured total earth pressure on the spring level is growing at less rate with time. The measured earth pressure keeps constant after 4 months after tail passing.

As shown in Figure 6(b), the figure shows the changes of the earth pressure and water pressure acting on the lining with time at Section-b, ring 1094. The measured total earth pressure on the bottom has experienced a fluctuation within a month after tail passing. The measured total earth pressure on the bottom level is growing at a rapid rate during one to two weeks after tail passing and the maximum value reaches $700 \mathrm{kPa}$. Then the measured earth pressure decreases two weeks after tail passing and the value keeps constant for a long time. The measured total earth pressures on the crown level and on the spring line level do not have a significant change with time.

As shown in Figure 6(c), the figure shows the changes of the earth pressure and water pressure acting on the lining with time at Section-c, ring 1210. The most previous measured data were not obtained due to the construction disturb. From the partial measured data, the measured earth pressures on the bottom and on the crown were relatively stable and the measured earth pressure on the spring line had a fluctuation three months after tail passing.

As shown in Figure 6(d), the figure shows the changes of the earth pressure and water pressure acting on the lining with time at Section-d, ring 1384. The measured total earth pressures, on the crown, on the spring line and on the bottom, do not have a relative fluctuation with time. 


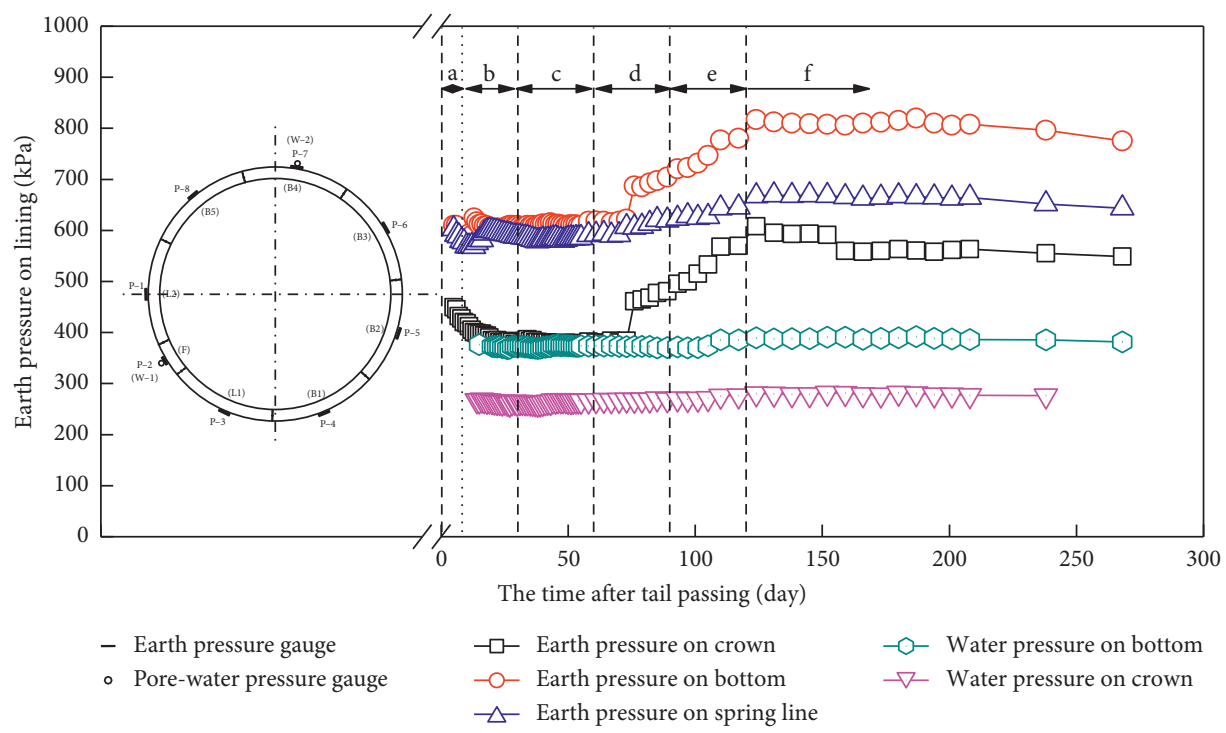

(a)

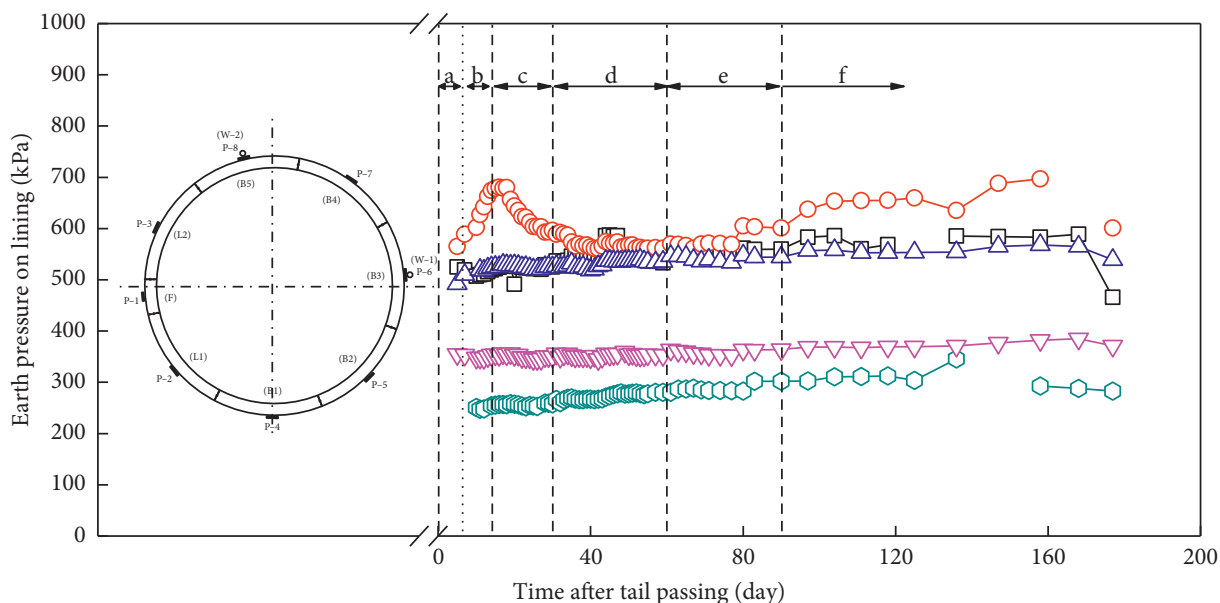

- Earth pressure gauge

- Pore-water pressure gauge

$-\square-$ Earth pressure on crown $\quad-0$ - Water pressure on spring line $-\circ-$ Earth pressure on bottom $\quad-\nabla-$ Water pressure on crown $\triangle$ Earth pressure on spring line

(b)

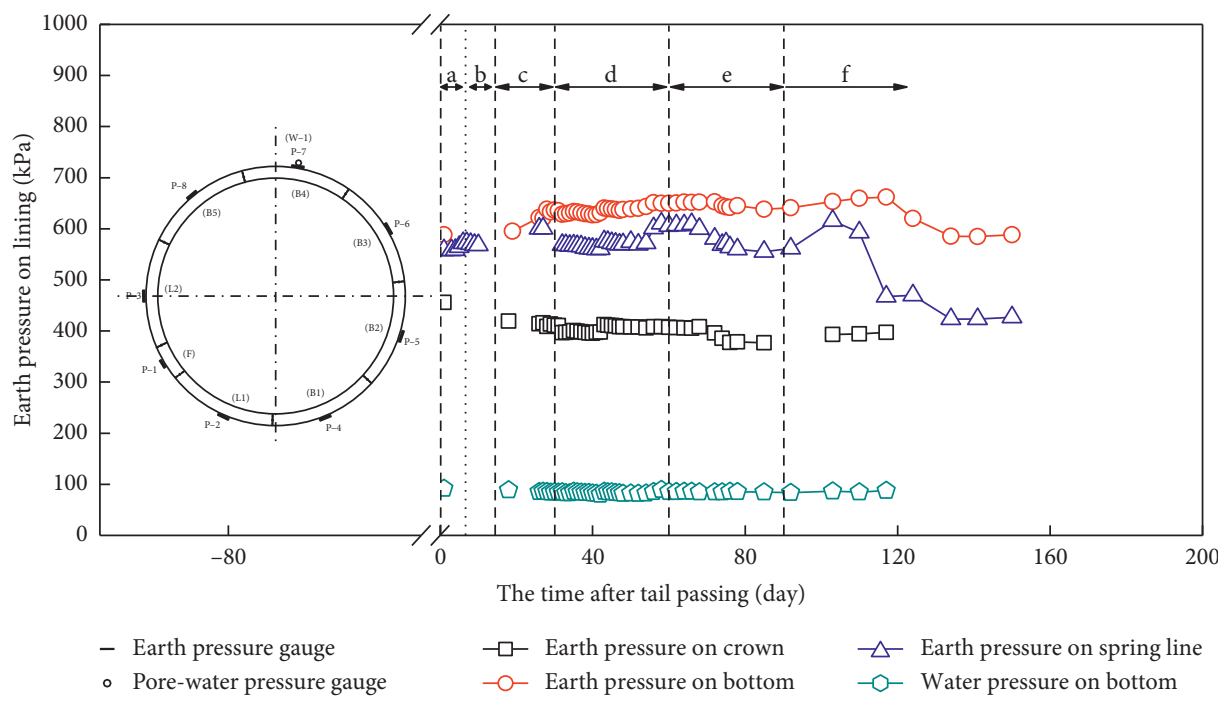

(c)

Figure 6: Continued. 


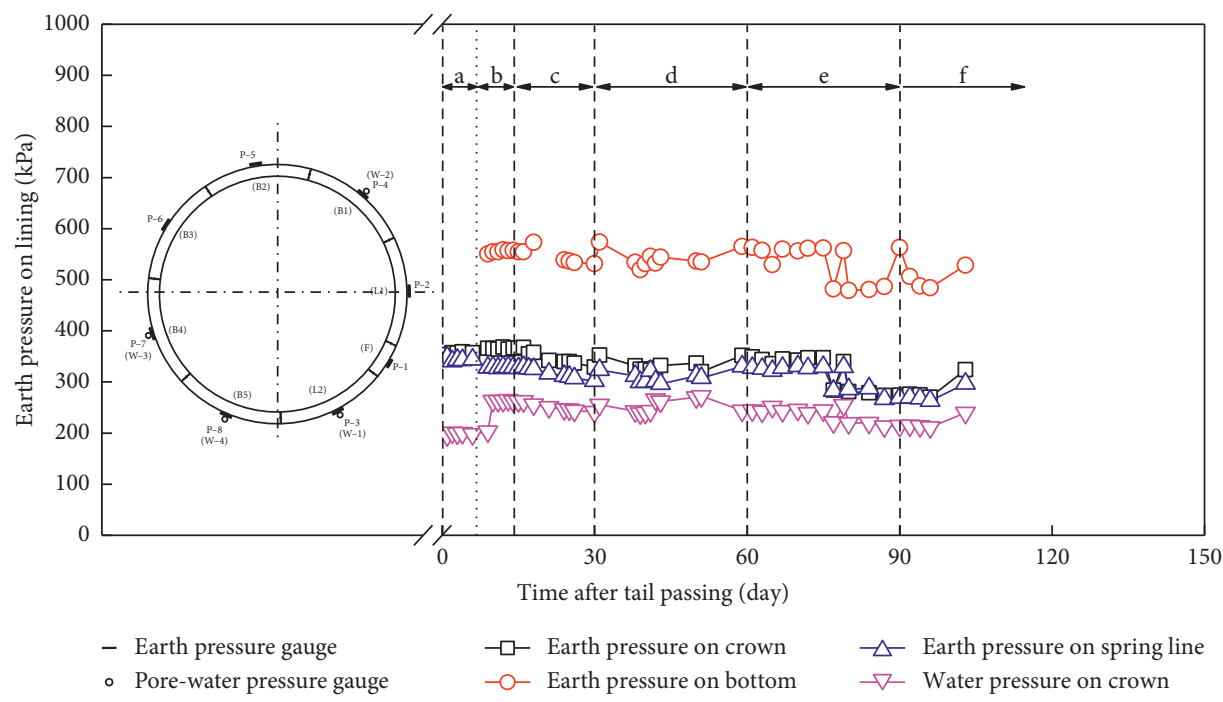

(d)

FIGURE 6: Distribution of earth pressure and water pressure with time: (a) distribution of the earth pressure and water pressure (Section-a, ring 479), (b) distribution of the earth pressure and water pressure (Section-b, ring 1094), (c) distribution of the earth pressure and water pressure (Section-c, ring 1210), and (d) distribution of the earth pressure and water pressure (Section-d, ring 1384).

Overall, the changes in the total earth pressure acting on the lining can occur over a long period after the shield machine tail passed. However, the water pressure stays relatively constant after the shield tail of the shield machine has passed. The time after tail passing is divided into one week, two weeks, one month, two months, and three months to clearly determine the measured earth pressure and water pressure.

The variation trend for the earth pressure with time showed a main change in 3 phases. In the first phase, when the tunnel lining passed the TBM tail, the earth pressure will have a certain fluctuation that may last for about one or two weeks. In the second phase, the earth pressure may decrease or increase at a slight rate for construction reasons, such as the second grouting injection behind the segment. In the third phase, the earth pressure is relatively constant and may last two or three months after the tail passing. The final earth pressure can be considered to be the design load in the serviceability limit state. The other section's (Figures 6(b)$6(d)$ ) earth pressure and water pressure measured on-site showed a similar trend to the results in Figure 6(a).

\subsection{The Earth Pressure and Water Pressure in the Circum-} ferential Direction. Figure 7 shows the measured total earth pressure and water pressure distributions at different stages after shield tail passing. From the results, most of the earth pressure gradually changes over a long period, which is also observed in other field measurements [3]. Due to the different influencing factors, such as construction operations, grouting pressure, and the amount of grouting, the distribution of the earth pressure is uneven to some extent.

As shown in Figure 7(a), at Section-a, ring 479, the magnitude and distribution of the measured earth pressure varied with time. The measured total earth pressure on the bottom is larger than that on the crown level and on the spring level. The total overburden earth pressure $P=r H+P_{\mathrm{w}}$ ( $r$ : submerged unite weight) adopted as the design load reaches $632.53 \mathrm{kPa}$. The measured total earth pressure is $548.92 \mathrm{kPa}$ on the tunnel crown level when the segment is 9 months after tail passing. The measured total earth pressure measured accounts for approximately $86.78 \%$ of the amount of the effective overburden earth pressure plus the water pressure.

As shown in Figure 7(b), at Section-b, ring 1094, the magnitude of the measured total earth pressure varied less with time and the distribution of the earth pressure is uneven. The measured total earth pressure is $465.73 \mathrm{kPa}$ at the tunnel crown level. The earth pressure measured accounts for approximately $82.90 \%$ of the amount of the effective overburden earth pressure plus water pressure.

As shown in Figure 7(c), at Section-b, ring 1210, the magnitude of the measured total earth pressure varied less with time and the distribution of the earth pressure is uneven. The measured total earth pressure is $396.94 \mathrm{kPa}$ at the tunnel crown level. The measured total earth pressure accounts for approximately $80.34 \%$ of the amount of the effective overburden earth pressure plus water pressure.

As shown in Figure 7(d), at Section-b, ring 1384, the magnitude of the measure earth pressure varied less with time and the distribution of the earth pressure is uneven. The measured total earth pressure is $323.84 \mathrm{kPa}$ at the tunnel crown level. The measured total earth pressure accounts for approximately $78.12 \%$ of the amount of the effective overburden earth pressure and water pressure.

In addition, a further analysis revealed that distribution of the earth pressure measured acting on the lining located below the Yangtze River levees (Figure 7(a)) may be different from those below the Yangtze River (Figures 7(b)$7(\mathrm{~d}))$. The earth pressure measured on the lining located 

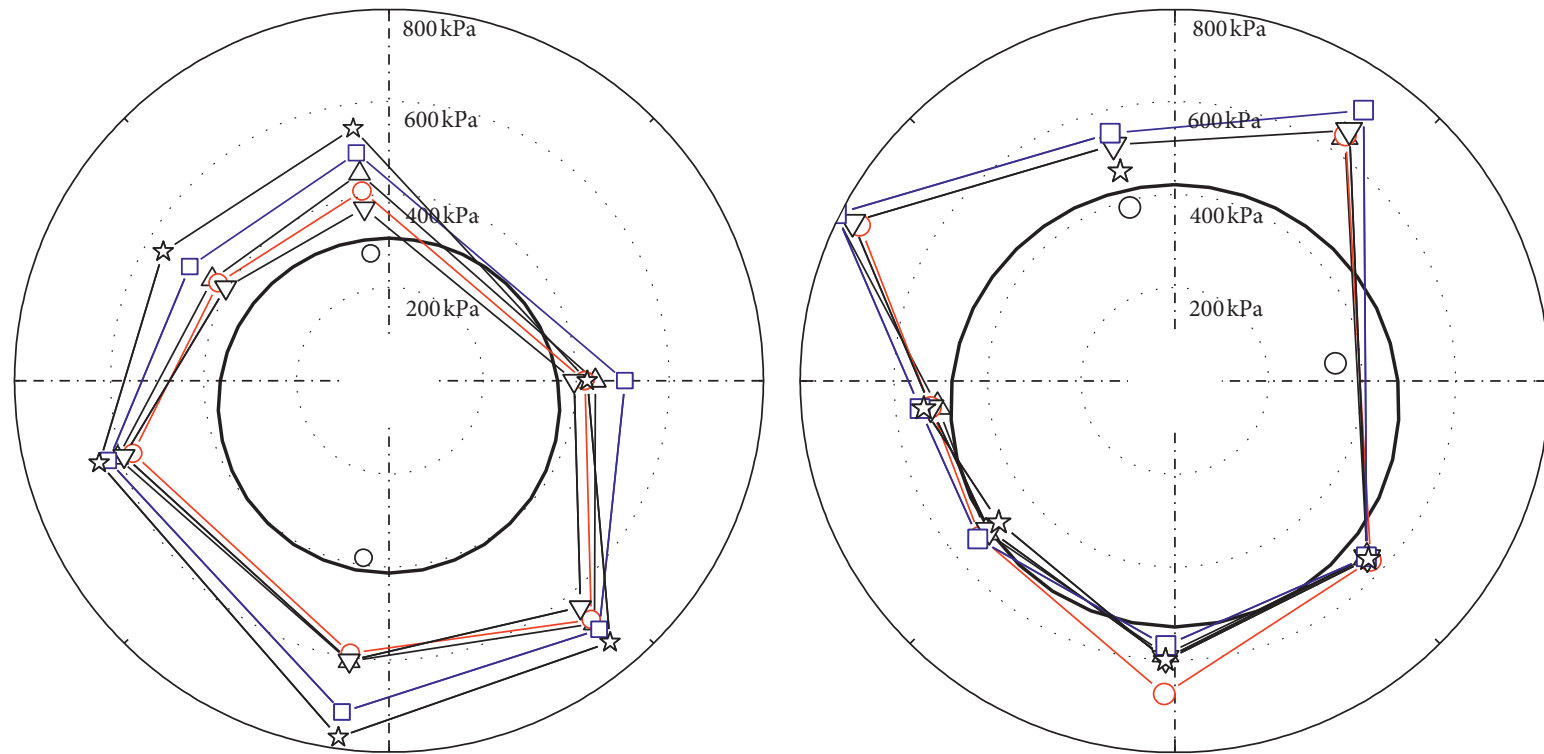

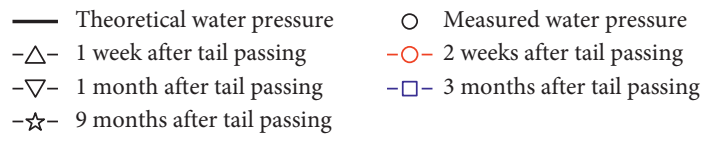

(a)

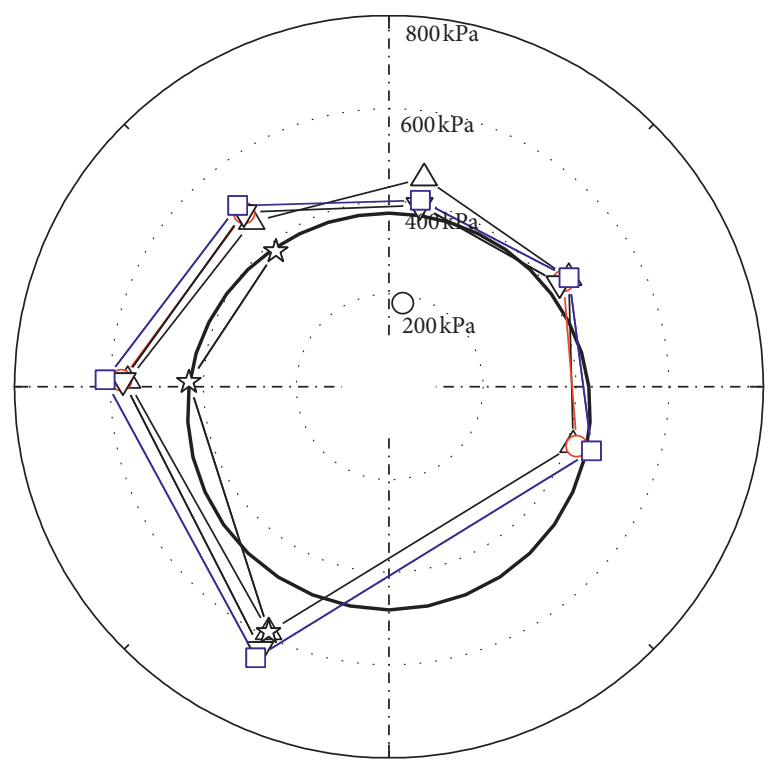

- Theoretical water pressure

$-\triangle^{-} 1$ week after tail passing

$-\nabla-1$ month after tail passing

-5 months after tail passing

(c)

\begin{abstract}
- Measured water pressure
$-0-2$ weeks after tail passing

$-\square-3$ months after tail passing
\end{abstract}

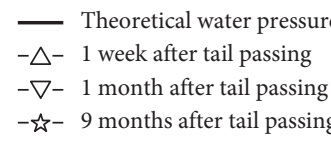

O Measured water pressure

$-\bigcirc-2$ weeks after tail passing

$-\square-3$ months after tail passing

(b)

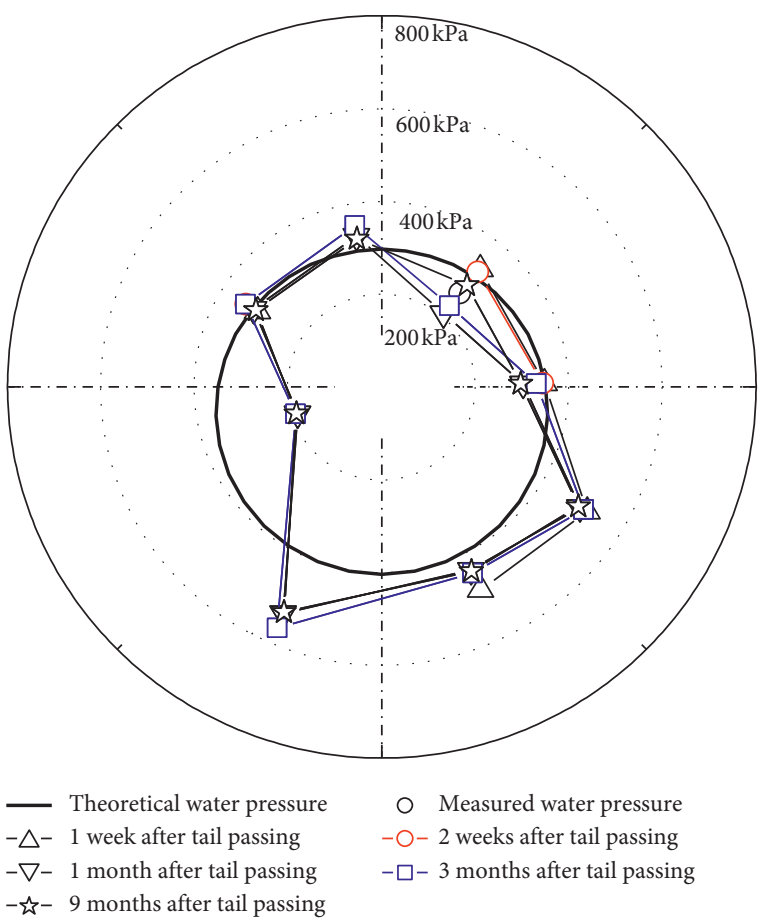

(d)

Figure 7: Distribution of the earth pressure and water pressure at different stages: (a) Section-a (ring 479), (b) Section-b (ring 1094), (c) Section-c (ring 1210), and (d) Section-d (ring 1384).

below the levees is much larger than the theoretical hydrostatic pressure. However, the earth pressure measured on the lining located below the river corresponds to the theoretical hydrostatic pressure acting on the tunnel lining. This is also proven by other results measured in sandy diluvium [3].

\section{Comparison between Observation and Design Values}

To compare the observed earth pressure and the theoretical value, the theoretical earth pressures at the monitoring locations, including the full overburden 
pressure and Terzaghi's reduced pressure, were calculated. The full overburden vertical earth pressure is calculated by [15-17]

$$
P=\sum \gamma_{i} h_{i}
$$

where $P$ is the vertical earth pressure on the top of the shield tunnel, $\gamma_{\mathrm{i}}$ is the soil weight, and $h_{i}$ is the thickness of the soil layer. A reduced earth pressure theory was proposed by Terzaghi [18] where the reduced vertical earth pressure is based on the balance theory of loose media and the concept of stress transfer. The influencing factors, including tunnel diameter, internal friction angle, and soil cohesion, were considered to determine the Terzaghi loosening earth pressure (see Figure 8). The reduced earth pressure calculated by Terzaghi's formula can be adopted in accordance with [19]

$$
\begin{aligned}
\sigma_{y}= & \frac{B_{1} \gamma-c}{k_{0} \tan \varphi}\left(1-e^{-\left(k_{0} H \tan \varphi / B_{1}\right)}\right) \\
& +P_{0} e^{-\left(k_{0} H \tan \varphi / B_{1}\right)}, \\
B_{1}= & R_{0} \cot \left(\frac{(\pi / 4)+(\varphi / 2)}{4}\right),
\end{aligned}
$$

where $B_{1}$ is the width of the collapsed area above the tunnel crown, $k_{0}$ is the lateral pressure coefficient, and $c$ and $\varphi$ are the cohesion and internal soil friction angle, respectively.

Figure 9 compares the observed ground pressure and the theoretical design values for different $H / D$ ratios. In Figure 9, the $H / D$ ratio represents the overburden soil depth over the tunnel outer diameter, the $P / P_{\mathrm{f}}$ ratio represents the observed ground pressure over the calculated full overburden ground pressure, the $P / P_{\mathrm{f}}$ ' ratio represents the observed ground pressure over the calculated Terzaghi's reduced ground pressure plus hydrostatic pressure, and the $\mathrm{P} / \mathrm{P}_{\mathrm{w}}$ represents the observed ground pressure over the calculated theoretical hydrostatic pressure, respectively. All the observed vertical ground pressure values on the crown are smaller than those calculated by the weight of the full overburden soil. When the $H / D$ ratio is larger than 3 (Section-a, ring 479), the ground pressures obtained from the earth pressure cell measurements are larger than those calculated by Terzaghi's formula plus hydrostatic pressure and are smaller than those calculated by the full overburden formula. Due to the location of the section, the cross section on-site is below the Yangtze River levees, and the observed ground pressure is much larger than the theoretical hydrostatic pressure. When the cross section of the tunnel is below the Yangtze river and the $H / D$ ratio ranges from 1.0 to 1.5 , the observed ground pressure is much closer to the theoretical hydrostatic pressure, the soil pressure acting on the shield lining is very small, and only the hydrostatic pressure acts on the shield tunnel lining according to the field measurements. These results matched previous examinations [3]. Therefore, the river level above the shield tunnel should be considered for use as the design value of the ground pressure with high water pressure.

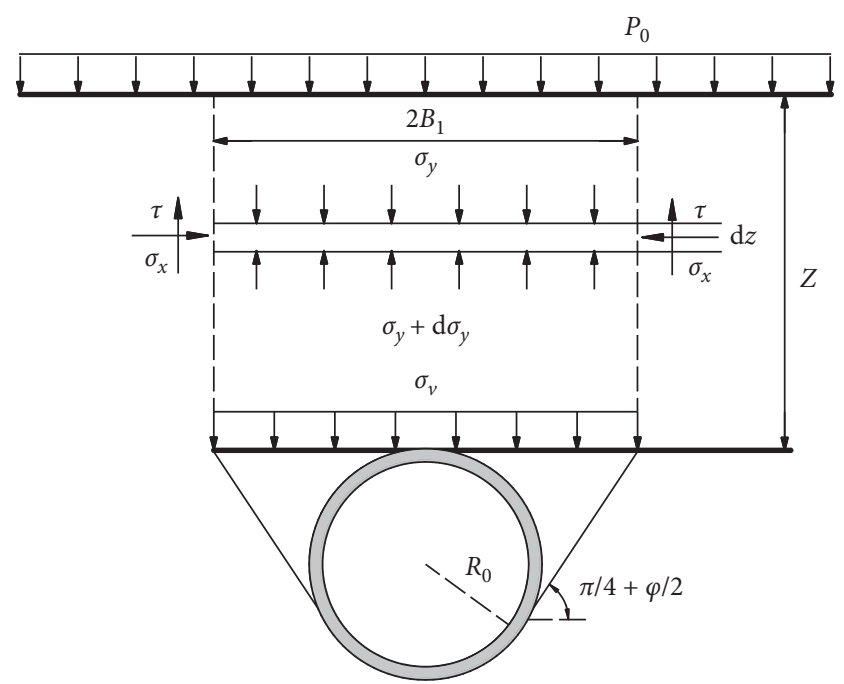

FIGURE 8: Reduced earth pressure calculated by Terzaghi’s formula.

\section{Influencing Factors on the Load Acting on the Tunnel Lining}

5.1. The Tunnelling Construction. The load acting on the segments is influenced by the operational control of the shield tunnel machine, the backfill grouting method, squeezing of the tail brushes, and other impermanent construction loads. The influencing factor of backfill grouting and tail brushes on the shield segments were confirmed in some previous laboratory and in-field tests [3]. There are no detailed earth pressure measurements associated with tail brushes on the segments for this project, but these have been carried out in the field by other researchers [3]. Figure 10 shows the detailed variations of the earth pressure measured by the earth pressure cells installed on the segments to determine the influence of the tail brushed on the segments. The result revealed that the load on the shield tunnel lining will become the maximum when the shield machine is driving. The maximum earth pressure values were approximately two times as large as the ground earth pressure.

In addition, the maximum pressure may be influenced by the backfill grouting pressure and the amount of grouting. A higher earth pressure acting on the lining may result from a higher backfill grouting pressure. The amount of grouting for this project used a range from $130 \%$ to $150 \%$. The maximum values are approximately larger than $30 \%$ of the stable value of the measured pressure. However, the load influenced by the backfill grouting and tail brushes does not last for a long time and only momentarily affects the tunnel segments.

5.2. The Buried Depth of the Shield Tunnel. The observed ground pressures in this paper are closer to the earth pressure values calculated by Terzaghi's formula plus the water pressure. All of the buried depths of the measured cross section are larger than the outer diameter of the tunnel, which indicated that a soil arch exists for these conditions. However, when the ratio of height to the outer diameter is 


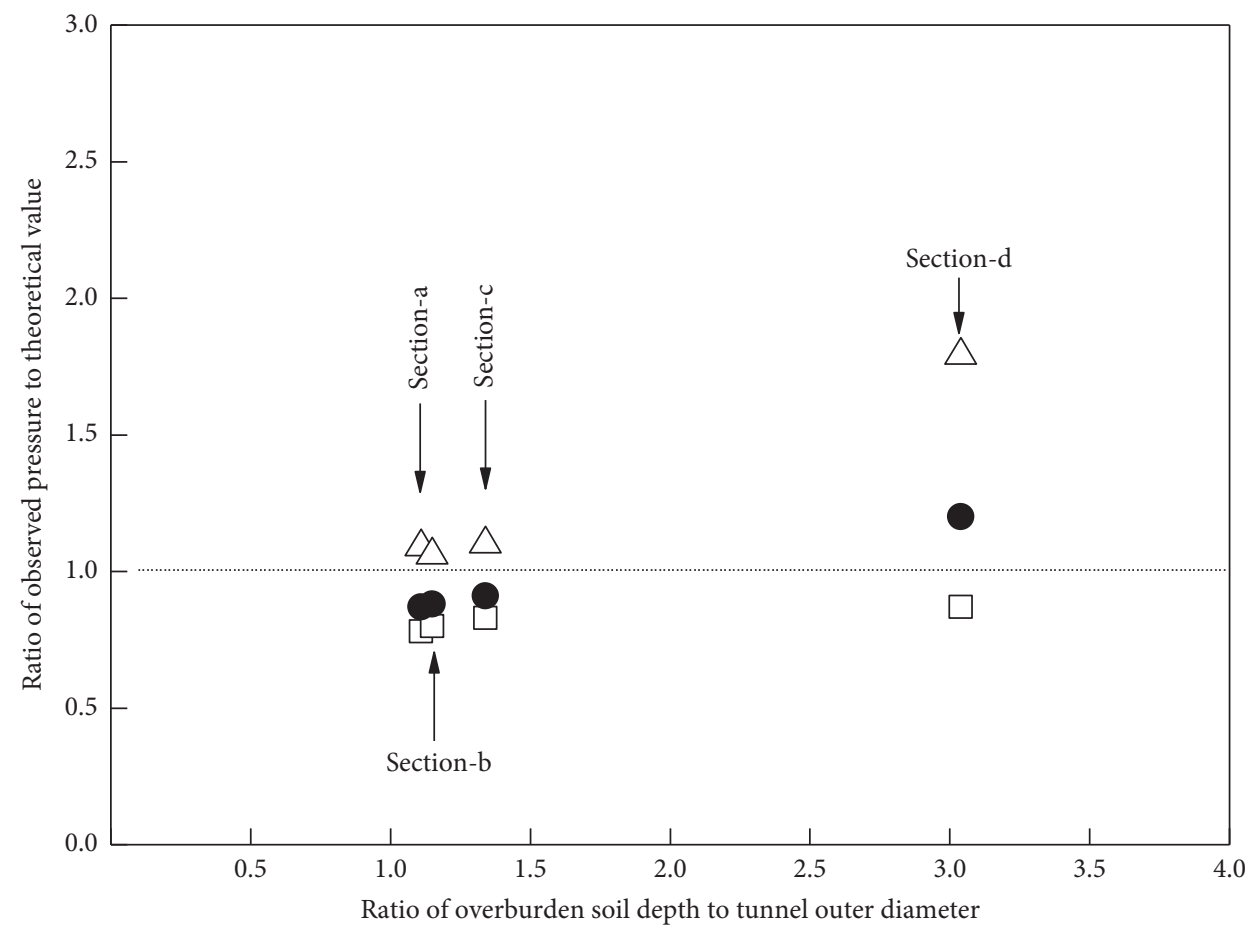

Observed ground pressure over calculated full overburden ground pressure

Observed ground pressure over calculated Terzaghi's reduced pressure plus hydrostatic pressure

$\triangle$ Observed ground pressure over calculated theoretical hydrostatic pressure

FIGURE 9: Relationship between the observed and theoretical pressure.

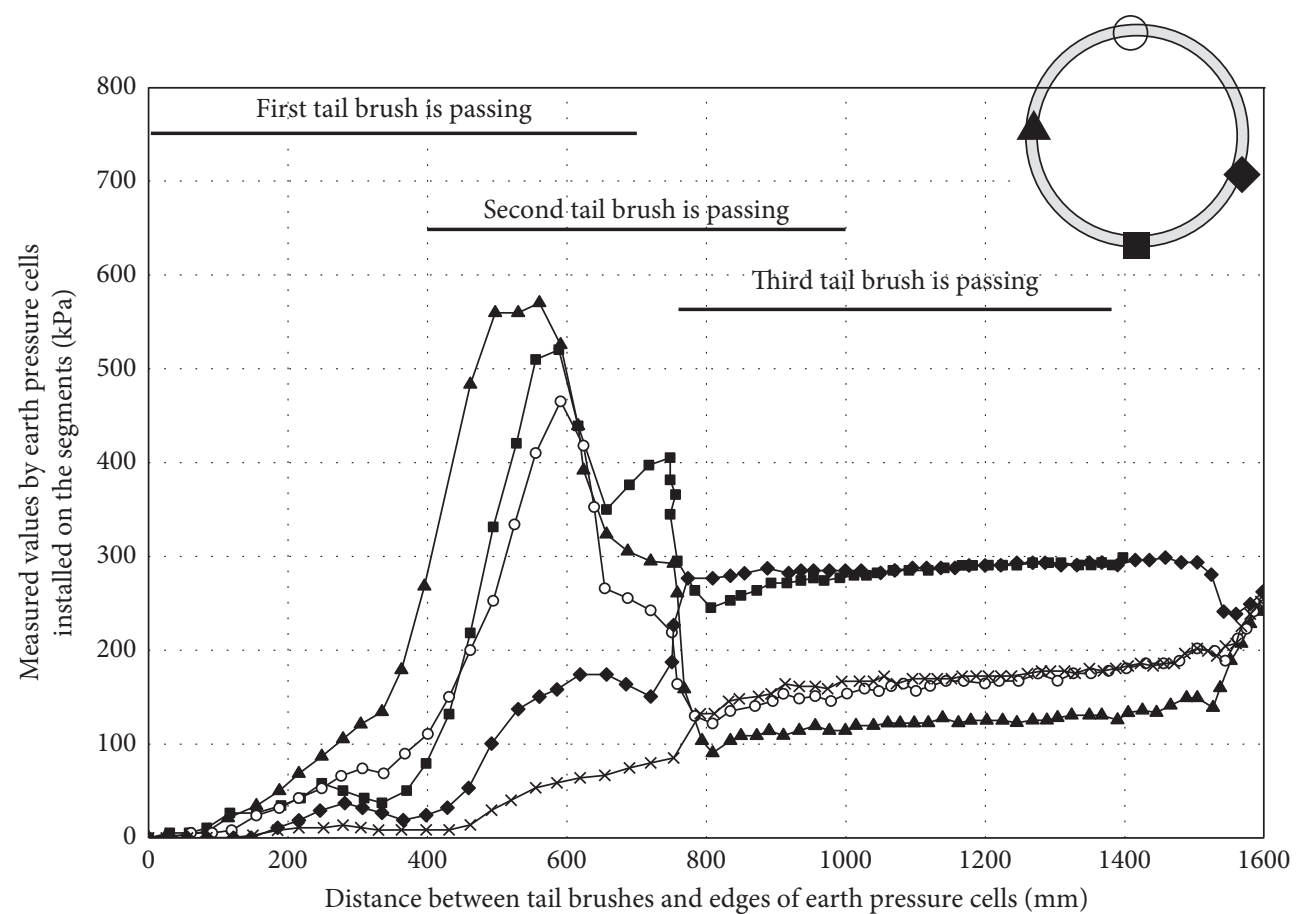

FIgURE 10: Influence of the tail brushes on the segments (reproduced from Koyama [3]). 
TABLE 3: Observed total earth pressure acting on the lining on the crown and the theoretical calculations.

\begin{tabular}{|c|c|c|c|c|}
\hline Section & $\begin{array}{l}\text { Section-a } \\
\text { (ring 479) }\end{array}$ & $\begin{array}{l}\text { Section-b } \\
\text { (ring 1094) }\end{array}$ & $\begin{array}{l}\text { Section-c } \\
\text { (ring 1210) }\end{array}$ & $\begin{array}{l}\text { Section-d } \\
\text { (ring 1384) }\end{array}$ \\
\hline Overburden soil depth over tunnel outer diameter & 3.04 & 1.34 & 1.15 & 1.11 \\
\hline Calculated by full total overburden ground pressure $(\mathrm{kPa})$ & 632.53 & 561.81 & 494.06 & 414.53 \\
\hline Terzaghi's reduced pressure plus hydrostatic pressure $(\mathrm{kPa})$ & 457.35 & 511.54 & 450.66 & 372.13 \\
\hline Observed vertical total earth pressure $(\mathrm{kPa})$ & 548.92 & 465.73 & 396.94 & 323.84 \\
\hline Observed vertical total earth pressure over full overburden ground pressure & 0.87 & 0.83 & 0.80 & 0.78 \\
\hline $\begin{array}{l}\text { Observed vertical total earth pressure over calculated Terzaghi's reduced } \\
\text { pressure plus hydrostatic pressure }\end{array}$ & 1.20 & 0.91 & 0.88 & 0.87 \\
\hline Observed vertical total earth pressure over theoretical hydrostatic & 1.79 & 1.10 & 1.06 & 1.09 \\
\hline
\end{tabular}

less than 1 , the pressure on the crown is nearly equal to the overburden soil weight, and there is no fairly arch acting on the tunnel lining $[20,21]$. Additionally, the observed ground pressure increases the soil height over the tunnel, despite the existence of a soil arch.

5.3. Influence of the Yangtze River Level. The water pressure acting on the shield tunnel lining is the buoyancy. Therefore, the ground pressure acting on the lining is influenced by the height of the river level. The influence of the river level on the shield segments was examined in this project. When the ratio of $H_{\mathrm{w}}$ to $D$ is larger than 2 and the overburden depth is less than the river level, the ground pressure observed infield is associated with the river level. Further analysis indicated that the ground pressure increases with the river level. Section-c and Section-d have roughly the same soil overburden height, $12.9 \mathrm{~m}$ and $12.5 \mathrm{~m}$, respectively, but there is $7.67 \mathrm{~m}$ river level difference between the two cases. This river level difference results in a difference in the ground pressure acting on the lining of $73.1 \mathrm{kPa}$. Based on these results, the water pressure is dominant under these conditions (Table 3).

\section{Conclusions}

In this paper, through a series of field investigations on the shield tunnel lining pressure at different soil depths and river levels, the behaviour of the load on segmental linings had been examined and compared to the design values. The factors influencing the pressures were also discussed. Based on the field results and analyses, the following conclusions can be drawn:

(1) The pressure observed acting on the lining demonstrated that the total ground pressure distribution and the ground pressure amount are different for different overburden depths. The distributions are uneven due to construction reasons.

(2) The water pressure measured on-site is approximately equal to the theoretical hydrostatic pressure. The water pressure acting on the shield tunnel lining does not fluctuate with the shield tunnel excavation.

(3) The maximum pressure is measured in the process of backfill grouting, and the maximum values are approximately larger than $30 \%$ of the stable value of the measured pressure. It is thought that one of the reasons is the existence of higher grouting pressure and the amount of backfill grouting.

(4) With high water pressure and the river level above the shield tunnel, the water pressure is dominant and the observed total earth pressure is nearly equal to the water pressure.

\section{Data Availability}

The data used to support the findings of this study are included within the article.

\section{Conflicts of Interest}

The authors declare that there are no conflicts of interest regarding the publication of this paper.

\section{Acknowledgments}

This research was funded by the National Natural Science Foundation of China (no. 51808469), Shanghai Key Laboratory of Rail Infrastructure Durability and System Safety (no. R201902), and the Young Scholars Development Fund of SWPU (no. 201699010115).

\section{References}

[1] H. Mashimo and T. Ishimura, "Evaluation of the load on shield tunnel lining in gravel," Tunnelling and Underground Space Technology, vol. 18, no. 2-3, pp. 233-241, 2003.

[2] T. Hashimoto, T. Konda, J. Brinkman et al., "Simultaneous backfill grouting, pressure development in construction phase and in the long-term," in Tunnelling. A Decade of Progress GeoDelft 1995-2005, pp. 101-107, Taylor and Francis, Delft, The Netherlands, 2005.

[3] Y. Koyama, "Present status and technology of shield tunneling method in Japan," Tunnelling and Underground Space Technology, vol. 18, no. 2-3, pp. 145-159, 2003.

[4] X. Li, Z. Tian, Z. Yang et al., "Observed ground pressures and internal forces of the Shanghai Yangtze river tunnel," in Proceedings of Tunneling and Underground Construction, ASCE, Shanghai, China May 2014.

[5] J. Wang, J. Liu, X. Liu, Y. Jiang, and X. Liu, "In-site experiments on the swelling characteristics of a shield tunnel in expansive clay: a case study," KSCE Journal of Civil Engineering, vol. 21, no. 3, pp. 976-986, 2017.

[6] S. Zhou, X. Li, C. Ji, and J. Xiao, "Back-fill grout experimental test for discharged soils reuse of the large-diameter size slurry 
shield tunnel," KSCE Journal of Civil Engineering, vol. 21, no. 3, pp. 725-733, 2017.

[7] T. Hashimoto, "Observation of lining pressure due to shield tunnelling," in Proceedings of The 3rd International Symposium on Geotechnical Aspects of Underground Construction in Soft Ground, IS-Toulouse, Toulouse, France, October 2002.

[8] X. Li, S. Zhou, P. Wang et al., "Study of distribution law of earth pressure acting on shield tunnel lining based on in-situ data," Rock and Soil Mechanics, vol. 35, pp. 453-459, 2014, in Chinese.

[9] K. J. Bakker, F. de Boer, J. B. M. Admiraal, and E. P. van Jaarsveld, "Monitoring pilot projects using bored tunnelling: the second heinenoord tunnel and the botlek rail tunnel," Tunnelling and Underground Space Technology, vol. 14, no. 2, pp. 121-129, 1999.

[10] E. Bilotta and G. Russo, "Internal forces arising in the segmental lining of an earth pressure balance-bored tunnel," Journal of Geotechnical and Geoenvironmental Engineering, vol. 139, no. 10, pp. 1765-1780, 2013.

[11] L. Han, G.-l. Ye, J.-j. Chen, X.-h. Xia, and J.-h. Wang, "Pressures on the lining of a large shield tunnel with a small overburden: a case study," Tunnelling and Underground Space Technology, vol. 64, pp. 1-9, 2017.

[12] T. Hashimoto, G. L. Ye, J. Nagaya et al., "Study on earth pressure acting upon shield tunnel lining in clayey and sandy grounds based on field monitoring," in Geotechnical Aspects of Underground Construction in Soft Ground: Proceedings of the 6th International Symposium, CRC Press, Shanghai, China, 2008.

[13] K.-H. Chen and F.-L. Peng, "An improved method to calculate the vertical earth pressure for deep shield tunnel in Shanghai soil layers," Tunnelling and Underground Space Technology, vol. 75, pp. 43-66, 2018.

[14] X. Li, S. Zhou, H. Di, and P. Wang, "Evaluation and experimental study on the sealant behaviour of double gaskets for shield tunnel lining," Tunnelling and Underground Space Technology, vol. 75, pp. 81-89, 2018.

[15] W. Q. Ding, Z. Q. Yue, L. G. Tham, H. H. Zhu, C. F. Lee, and T. Hashimoto, "Analysis of shield tunnel," International Journal for Numerical and Analytical Methods in Geomechanics, vol. 28, no. 1, pp. 57-91, 2004.

[16] K. Feng, C. He, Y. Fang, and Y. Jiang, "Study on the mechanical behavior of lining structure for underwater shield tunnel of high-speed railway," Advances in Structural Engineering, vol. 16, no. 8, pp. 1381-1399, 2013.

[17] C. Lin, S. Wu, and T. Xia, "Design of shield tunnel lining taking fluctuations of river stage into account," Tunnelling and Underground Space Technology, vol. 45, pp. 107-127, 2015.

[18] K. Terzaghi, Theoretical Soil Mechanics, John Wiley \& Sons, New York, NY, USA, 1943.

[19] Y. H. Takano, "Guidelines for the design of shield tunnel lining," Tunnelling and Underground Space Technology, vol. 15 , pp. 303-331, 2000.

[20] H. Ohta, T. Takeuchi, and Y. Nishiwaki, "Performance of linings for shield driven tunnels-a survey on Japanese shield tunneling," International Symposium on Underground Construction in Soft Ground, A. A. Balkema, New Delhi, India, 1995.

[21] S. M. Wu, Z. Wang, and L. Wang, "Monitoring and analysis of the force and deformation of large section crossing-river tunnel during operation period," Journal of Zhejiang University (Engineering Science), vol. 47595, 2013, in Chinese. 